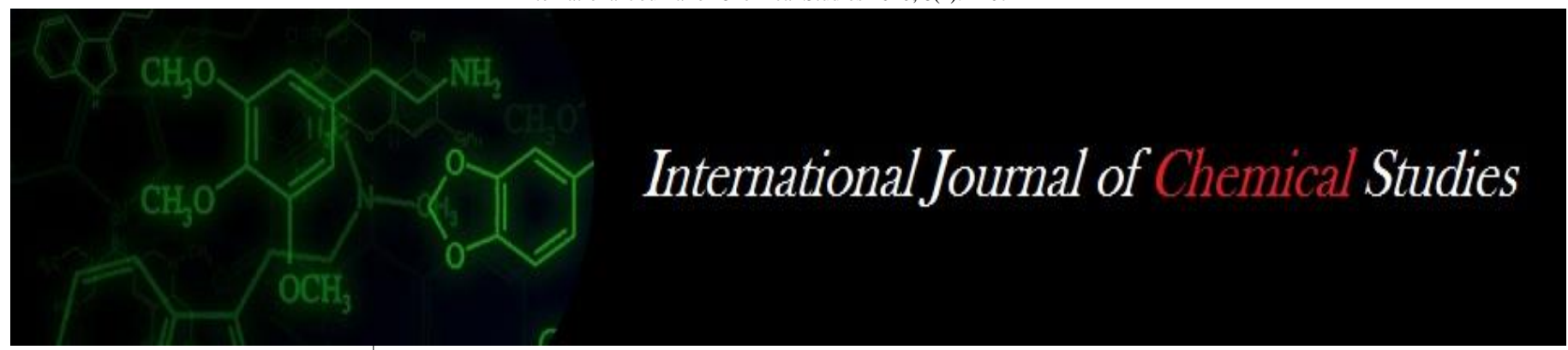

P-ISSN: 2349-8528

E-ISSN: 2321-4902

www.chemijournal.com

IJCS 2020; 8(2): 1107-1111

(C) 2020 IJCS

Received: 07-01-2020

Accepted: 09-02-2020

Sanyogita Chaudhary

Ph. D. Scholar's. Department of

Agronomy, GB. Pant University of Agriculture and Technology,

Pantnagar, US. Nagar,

Uttarakhand, India

Sumit Chaturvedi

Associate Professor. Department

of Agronomy, GB. Pant

University of Agriculture and

Technology, Pantnagar, US.

Nagar, Uttarakhand, India

\section{VC Dhyani}

Associate Professor. Department of Agronomy, GB. Pant

University of Agriculture and

Technology, Pantnagar, US.

Nagar, Uttarakhand, India
Corresponding Author: Sanyogita Chaudhary

Ph. D. Scholar's. Department of Agronomy, GB. Pant University of Agriculture and Technology,

Pantnagar, US. Nagar,

Uttarakhand, India

\section{Effect of crop diversification and residue management techniques on yield attributes, yield and soil nutrient}

\author{
Sanyogita Chaudhary, Sumit Chaturvedi and VC Dhyani
}

DOI: https://doi.org/10.22271/chemi.2020.v8.i2q.8915

\begin{abstract}
Green revolution prompts the development of rice wheat cropping system over the South Asian IndoGangetic Plains. This system is comprehensive in nature and prompts malicious consequences on soil health which is the most disturbing issue these days and the other issue which takes individuals consideration is the is the loads of residue generation. To Find the potential approaches to counter these issue an examination was directed at held during the Kharif season of 2017 at N. E. Borlaug Crop Research Centre of G.B. Pant University of Agriculture and Technology, Pantnagar, US Nagar, Uttarakhand to consider the impact diversification and different residue management technique on yield attributes, yield and soil health. Through this study it has been notified that the crop diversification through legumes leads to better soil property and increases the yield.
\end{abstract}

Keywords: Diversification, Revolution and approaches

\section{Introduction}

Rice-wheat cropping system (RWCS) is most dominant and mainstay of food self-sufficiency in many Asian countries by contributing $23 \%$ of food grain production (Verma et al., 2016) [27]. It covers an area of 13.5 million hectares across South Asian Indo-Gangetic Plains (IGP) (Ladha et al., 2003) ${ }^{[16]}$ and is the spine of social and economic growth of millions of people (Chauhan et al., 2012) ${ }^{[5]}$. However, this system has shown the sign of stagnant yield and declining soil health. The sustainability of the system has been questioned due to yield stagnation, soil health deterioration in the environment for more than two decades now (Das et al., 2017) ${ }^{[6]}$. Conventional RWCS leads to loads of issues such as ecological (declining underground water level, groundwater contamination, diverse weed flora, disease outbreak and insect pest); farming (degrading soil structure, declining soil health, residue management, least attended interim period, labor shortages, multiple nutrient deficiencies, declining crop response); livelihood (high energy requirement, reduce land productivity, lower water production, lower water efficiency, low wages) and climate (environmental pollution and global warming) (Bhatt et al., 2016) ${ }^{[3]}$. Intensive tillage, removal or burning of rice residues accelerates soil erosion, contamination of the atmosphere, soil depletion and affects functions of the ecosystem (Srinivasan et al., 2012) ${ }^{[23]}$. These constraints are widely found in rice-based cropping systems in the Indo- Gangetic plain where poor residue management, extensive fertilizer use and lack of diversification are normal practice. Sustainable module therefore requires an hour not only to mitigate these constraints but also to boost the efficiency of the ricebased cropping system for a projected 1.3billion population increase by 2025 in India (UNEP, 2008) ${ }^{[25]}$. Residue is another challenge which needs attention, particularly at RWCS. Approximately $500 \mathrm{Mt}$ of crop residues are produced annually according to the MNRE report (Agarwal et al., 2016) ${ }^{[1]}$. Cereal crops (corn, wheat, maize, millets) contribute $70 \%$ of the residue produced, while corn crops alone contribute $34 \%$ to crop residues, while wheat ranks second with $22 \%$ of crop residue. Hence, the removal of residues may have a direct effect on the depletion of soil nutrients. Residue control also affects the supply of micronutrients such as zinc and iron, which is an important factor in preserving the total balance of Silicon in rice (Dobermann which Fairhurst, 2000) ${ }^{[8]}$. Burning the rice residues causes environmental pollution, global warming, killing beneficial insects, generating net negative nutrient 
balance and also degrading the soil, reducing levels of organic matter and eventually contributing to degradation of soil health. Rice straw burning gaseous emissions are 70 percent $\mathrm{CO}_{2}, 7$ percent $\mathrm{CO}, 0.66$ percent $\mathrm{CH} 4$ and 2.09 percent N2O. Roughly $12 \mathrm{Mt}$ of rice straw is burned annually in Punjab alone, which causes about $0.7 \mathrm{Mt}$ of $\mathrm{N}$ losses (Samra et al., 2003) ${ }^{[21]}$. Alternative uses for rice straw management are possible to ensure maximum benefit without burning rice residues, for example using crop residues for manure, energy production, ethanol, biogas, residue gasification, pyrolysis (Yadwinder \& Sindhu, 2014) ${ }^{[28]}$. Residue incorporation also improves aggregate stability (Keller et al., 2007) ${ }^{[15]}$ and total porosity, resulting in increased soil moisture content as well as availability of water content (Jemai et al., 2013) ${ }^{[13]}$, with residue incorporation also improving aggregate stability (Keller et al., 2007) ${ }^{[15]}$ and total porosity and as a result, soil moisture content increases, as well as the amount of water content (Jemai et al., 2013) ${ }^{[13]}$. In view of all these issues and problems with the traditional rice wheat program, there is an urgent need to develop a technology that can resolve the issue of crop diversification and intensification and better use of crop residues for soil fertility improvement. In view of this, the present experiment was conceived with three different types of cropping method i.e. Rice- wheat, Rice- vegetable pea- maize (cob + fodder) and Rice- yellow sarson- groundnut by intensifying and diversifying crops to improve both soil and crop productivity.

\section{Material and methods \\ Experimental detail}

Experiment was conducted in Split Plot Design with three cropping systems viz. rice-wheat, rice-vegetable pea-maize and rice-yellow Sarson-groundnut in main plot and five residue management techniques viz. farmer's practice, $30 \%$ residue recycling, 30\% residue recycling + FYM @ $5 \mathrm{t} \mathrm{ha}^{1}$, $30 \%$ residue recycling + Biogas slurry@ $2 \mathrm{t} \mathrm{ha}^{-1}$ and 30\% residue recycling + Vermicompost @ $2 \mathrm{t} \mathrm{ha-}^{-1}$ replicated thrice. The residue was incorporated in the field in all the treatments except control $\left(\mathrm{C}_{1} \mathrm{~T}_{1}, \mathrm{C}_{2} \mathrm{~T}_{1}\right.$ and $\left.\mathrm{C}_{3} \mathrm{~T}_{1}\right)$. Based on crop rotation, $30 \%$ crop residue of the preceding crop was incorporated i.e. $30 \%$ of the total residue produced as depicted below. The residue was incorporated by ploughing followed by harrowing.

Table 1: Amount and date of residue incorporated and the percentage of nutrient present in organics applied

\begin{tabular}{|c|c|c|c|c|c|}
\hline Crop & \multicolumn{2}{|c|}{$\begin{array}{c}\text { Residue } \\
\text { produced (q/ha) }\end{array}$} & $\begin{array}{c}\text { Amount applied } \\
(\mathbf{q} / \mathbf{h a})\end{array}$ & $\begin{array}{c}\text { Date of residue } \\
\text { application }\end{array}$ \\
\hline Wheat & \multicolumn{2}{|c|}{60} & \multicolumn{2}{c|}{18} & $15 / 04 / 2017$ \\
\hline Groundnut & \multicolumn{2}{|c|}{40.5} & \multicolumn{2}{c|}{12.15} & $28 / 06 / 2017$ \\
\hline Maize & \multicolumn{2}{|c|}{116.7} & \multicolumn{2}{|c|}{35.01} & $18 / 06 / 2017$ \\
\hline Organics & $\mathbf{C \%}$ & $\mathbf{N \%}$ & $\mathbf{P \%}$ & $\mathbf{K} \%$ & $\mathbf{C}: \mathbf{N}$ \\
\hline FYM & 16.2 & 0.59 & 0.26 & 0.50 & 27 \\
\hline Vermicompost & 24.5 & 1.21 & 0.78 & 0.90 & 20 \\
\hline Biogas slurry & 15.96 & 1.05 & 0.45 & 0.55 & 15 \\
\hline
\end{tabular}

The organics used in the experiment were FYM, vermicompost and biogas slurry. FYM @ 5t/ha, vermicompost @2t/ha and biogas slurry@2t/ha; was applied just before puddling as per the treatment so that it gets mixed in the soil. The samples of organics were taken and through laboratory analysis, the $\mathrm{N}, \mathrm{P}$ and $\mathrm{K}$ percentage present in organics was calculated.

The treatments were replicated with size $3 \times 8.3 \mathrm{~m}^{2}$. Twentytwo days old rice seedlings of "HKR-47" were transplanted in
July. In all the treatments nitrogen, phosphorus, potassium and zinc were supplied through urea, diammonium phosphate, muriate of potash and zinc sulphate, respectively. The nitrogen is applied in three split doses. Entire $\mathrm{P}$ and $\mathrm{K}$ and $50 \mathrm{~kg} \mathrm{~N}$ were applied as basal. However, the $1^{\text {st }}$ top dressing was done at 28 DAT and $2^{\text {nd }}$ top dressing was done at 49 DAT through Green seeker. The foliar zinc was sprayed 10 and 20 days after transplanting of rice. Harvesting was done manually when more than 90 per cent of grains in the panicle were fully ripe and free from greenish tint. The observation for growth, development was recorded from the sampling area under field condition.

\section{Yield attributes}

Yield attributing were recorded at maturity is given in table 1. Number of panicles $\mathrm{m}^{-2}$ was counted. The total number of grain per panicle was calculated by dividing the total number of grain to the total number of panicles. The panicle length measured with the help of meter scale in centimetre. One thousand grains were counted from each plot and weighed to get thousand grains weight in grams. Ten panicles were harvested and threshed manually. After cleaning and drying the weight was recorded and converted to $\mathrm{m}^{-2}$. The grain weight per panicles was obtained by grain weight $\mathrm{m}^{-2}$ divided by number of panicles $\mathrm{m}^{-2}$. Grain yield is obtained after threshing and cleaning. The grain yield was converted to $\mathrm{tha}^{-1}$ after adjusting grain moisture at $10 \%$.

\section{Soil parameters}

Composite soil sample of each plot was collected by core from $0-15 \mathrm{~cm}$. The samples were air dried in shade on polythene sheets. After drying, samples were crushed on hard wooden slab with the help of wooden roller and passed through $2 \mathrm{~mm}$ sieve and stored in labelled polythene bags for further chemical analysis. Available $\mathrm{N}$ was determined by alkaline $\mathrm{KMnO}_{4}$ method given by Subbiah and Asija (1956) ${ }^{[24]}$. Available P was extracted by Olsen's method (Olsen et al., 1954) ${ }^{[19]}$. Available $\mathrm{K}$ in soil was determined by extraction with $1 \mathrm{~N}$ ammonium acetate of neutral $\mathrm{pH}$ and $\mathrm{K}$ concentration in soil extract was determined by flame photometer (Hanway and Heidel, 1952) ${ }^{[11]}$. Soil parameter is given in table 2 .

\section{Result and discussion \\ Yield and Yield attributes}

Residue management through organics and diversification through legumes have significant effect over different yield parameter and grain yield. The number of panicles $\mathrm{m}^{-2}$ was recorded maximum in $\mathrm{C}_{3}$ which was significantly higher than $\mathrm{C}_{1}$ and $\mathrm{C}_{2}$. The percent increase in number of panicles in $\mathrm{C}_{3}$ was 7.22 and 3.48 percent over $\mathrm{C}_{1}$ and $\mathrm{C}_{2}$, respectively. The panicle length $(\mathrm{cm})$ was observed maximum in $\mathrm{C}_{3}(28.4 \mathrm{~cm})$ and was at par with $\mathrm{C}_{2}$. The minimum panicle length was observed in $C_{1}$ (26.0). However, there was no significant response of number of grain panicle ${ }^{-1}$ and thousand grain weights $(\mathrm{g})$. The maximum grain weight panicle $^{-1}$ was notified in $\mathrm{C}_{3}(3.2 \mathrm{~g})$. The percent increase in grain weight panicle $^{-1}$ in $C_{3}$ was 14.3 and 10.3 per cent over $C_{1}$ and $C_{2}$, respectively. The maximum grain yield was observed under $\mathrm{C}_{3}$ but was statistically at par with $\mathrm{C}_{2}$. The percent increase in the grain yield in $\mathrm{C}_{3}$ over $\mathrm{C}_{1}$ is $11.23 \%$. Diversification through legumes results in addition of nitrogen to the soil through biological nitrogen fixation thereby help in enhancing the nutrient availability, enhaces the microbial activity (numbers of bacteria, fungi, and actinomycetes) and results in 
better growth and yield supported by (Davari et al., 2002) ${ }^{[7]}$. They reported that under rice-wheat-maize cropping system (RWMCS) the activity of microbes were higher i.e. numbers of bacteria, fungi, and actinomycetes in soil and improves soil health than under rice-wheat cropping system (RWCS) and results in higher number of panicles $\mathrm{m}^{-2}$. Further, supported by Sharma and Sharma, $2003^{[22]}$ that after two cycles of ricepotato-mungbean, rice-wheat-mungbean, rice-rapeseedmungbean and rice-clover cropping systems, respectively results in better availability of nutrients and increased the number of panicle $\mathrm{m}^{-2}$, panicle length, number of grains per panicle, grain weight panicle ${ }^{-1}$ and thousand grain weight.

Table 2: Yield attributes of rice as influenced by different cropping sequence and residue management techniques

\begin{tabular}{|c|c|c|c|c|c|c|}
\hline Treatments & \begin{tabular}{|c|}
$\begin{array}{c}\text { Number of panicle } \\
\mathbf{m}^{-2}\end{array}$ \\
\end{tabular} & $\begin{array}{c}\text { Panicle length } \\
(\mathrm{cm})\end{array}$ & $\begin{array}{c}\text { Number of grain } \\
\text { panicle }^{-1}\end{array}$ & $\begin{array}{c}\text { Grain wt. } \\
\text { Panicle }^{-1}(g) \\
\end{array}$ & \begin{tabular}{|c|}
1000 grain wt. \\
$(\mathrm{g})$
\end{tabular} & $\begin{array}{c}\text { Grain yield } \\
\left(t \mathbf{h a}^{-1}\right)\end{array}$ \\
\hline \multicolumn{7}{|c|}{ Cropping System } \\
\hline $\mathrm{C}_{1}$-Rice-wheat & 277 & 26.0 & 82 & 2.8 & 29.7 & 5.79 \\
\hline $\mathrm{C}_{2}$ - Rice-vegetable pea-maize & 287 & 27.9 & 82 & 2.9 & 29.7 & 6.21 \\
\hline $\begin{array}{l}\mathrm{C}_{3} \text { - Rice- yellow sarson- } \\
\text { groundnut }\end{array}$ & 297 & 28.4 & 84 & 3.2 & 29.8 & 6.44 \\
\hline $\operatorname{SEm}( \pm)$ & 2.16 & 0.40 & 0.43 & 0.04 & 0.05 & 0.19 \\
\hline $\mathrm{CD}$ at $\overline{5 \%}$ & 8.50 & 1.56 & NS & 0.17 & NS & 0.36 \\
\hline \multicolumn{7}{|c|}{ Residue management techniques } \\
\hline $\mathrm{T}_{1}$ - Farmer's practice & 261 & 25.5 & 81 & 2.8 & 29.2 & 5.42 \\
\hline $\mathrm{T}_{2}-30 \%$ residue recycling & 272 & 26.9 & 81 & 2.9 & 29.6 & 5.35 \\
\hline $\mathrm{T}_{3}-\mathrm{T}_{2}+\mathrm{FYM}$ & 300 & 27.2 & 82 & 3.0 & 29.8 & 6.45 \\
\hline $\mathrm{T}_{4}-\mathrm{T}_{2}+$ biogas slurry & 296 & 28.3 & 83 & 3.0 & 29.8 & 6.38 \\
\hline $\mathrm{T}_{5}-\mathrm{T}_{2}+$ vermicompost & 306 & 29.3 & 84 & 3.1 & 30.1 & 7.12 \\
\hline $\operatorname{SEm}( \pm)$ & 4.29 & 0.46 & 0.44 & 0.05 & 0.07 & 0.11 \\
\hline $\mathrm{CD}$ at $5 \%$ & 12.53 & 1.34 & 1.29 & 0.15 & 0.19 & 0.33 \\
\hline
\end{tabular}

Among the different residue management techniques, the maximum number of panicles $\mathrm{m}^{-2}$ were obtained in $\mathrm{T}_{5}$ (306) which were significantly higher than $T_{1}$ and $T_{2}$ but was statistically at par with $\mathrm{T}_{3}$ and $\mathrm{T}_{4}$. The number of panicles $\mathrm{m}^{-2}$ in $\mathrm{T}_{5}$ was increased to the tune of 17.24 percent, respectively over $T_{1}$. The maximum panicle length was observed in $T_{5}$ $(29.3 \mathrm{~cm})$ and the minimum was under $\mathrm{T}_{1}(25.5 \mathrm{~cm}) . \mathrm{T}_{5}$ and $\mathrm{T}_{4}$ have statistically similar panicle length. The maximum, number of grains panicle ${ }^{-1}$ and grain weight panicle was observed in $\mathrm{T}_{5}$ i.e. 84 and $3.1 \mathrm{~g}$ respectively and which was increased by 3.70 and 10.71 percent, respectively over $T_{1}$. However, significantly higher thousand grain weight was observed in $\mathrm{T}_{5}$ above all the other residue management techniques using organics. The thousand grain weight was increased in $T_{5}$ to the tune of 3.08 percent, respectively over $\mathrm{T}_{1}$. grain yield was significantly higher in $\mathrm{T}_{5}$ than all other treatments. The lowest grain yield was observed in $\mathrm{T}_{2}(30 \%$ residue recycling) which was at par with $\mathrm{T}_{1}$ (farmer's practice). The increase in grain yield in $T_{5}$ over $T_{1}$ was $31.36 \%$. Among residue management techniques through organics the yield attributes increased. Number of panicles $\mathrm{m}^{-}$
${ }^{2}$ were higher due to higher number of shoots per $\mathrm{m}^{-2}$ whereas, the better height and dry matter production helps in proper photosynthesis and translocation of photosynthates whereas, the nutrient availability was also higher due to incorporation of residue + organics which might have resulted in enhanced yield attributes. Bilkis et al. (2015) ${ }^{[4]}$ at Bangladesh reported that, maximum number of tiller hill $^{-1}$, panicle length, grain panicle $^{-1}$ and 1000 grain weight was observed in tricompost + chemical fertilizer but was statistically at par with vermicompost + chemical fertilizer followed by cow dung slurry + chemical fertilizer. Haque et al. (2014) ${ }^{[12]}$ reported that effective tillers hill ${ }^{-1}$, panicle length and grains panicle ${ }^{-1}$ and 1000-grain weight were enhanced significantly due to the application of organics along with soil test based chemical fertilizers over control. Bejbaruah et al. (2013) ${ }^{[2]}$ reported that yield attributes i.e. number of panicles $\mathrm{m}^{-2}$ was significantly increased by application of vermicompost (VC). Lungmuana et al. (2016) [17] reported that, the length of panicle of rice was significantly higher under integrated use of vermicompost and chemical fertilizer over control.

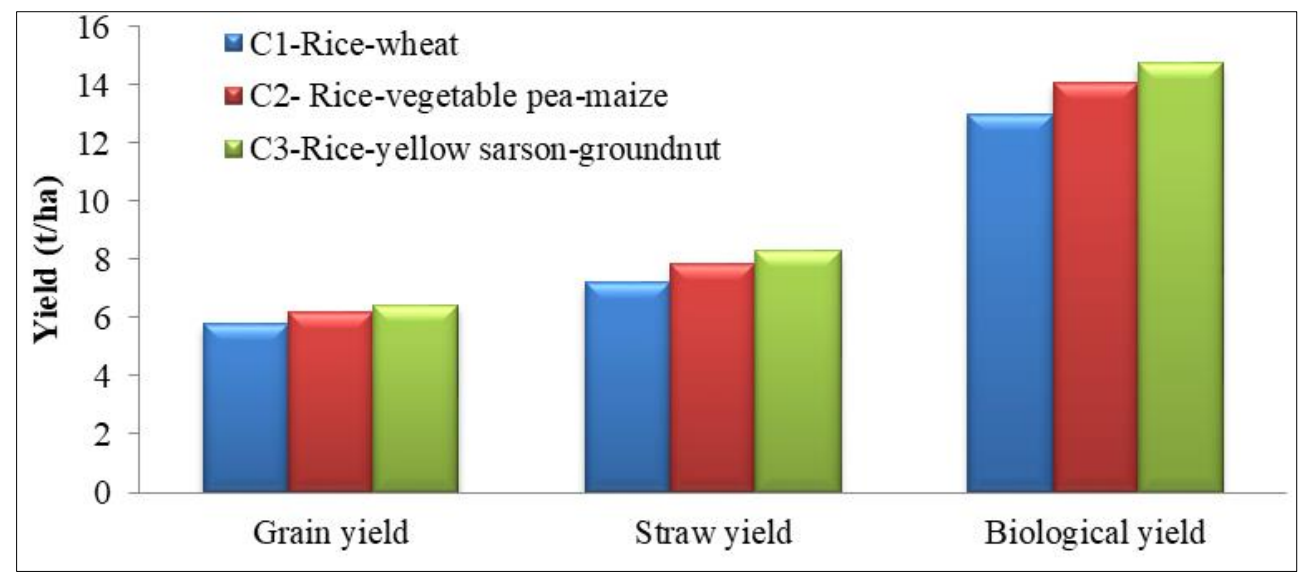

Fig 1: Grain, straw and biological yield as influenced by different cropping system 


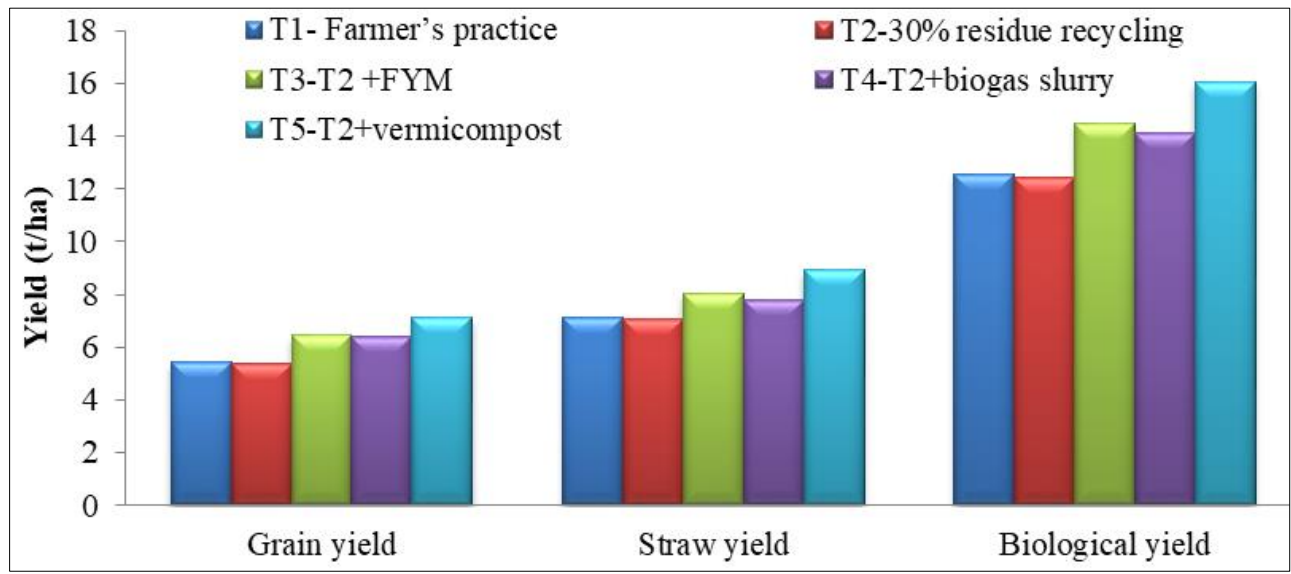

Fig 2: Grain, straw and biological yield as influenced by different residue management techniques

\section{Soil nutrient}

Among different diversified treatments the highest available nitrogen in soil was registered under $\mathrm{C}_{3}\left(230.07 \mathrm{~kg} \mathrm{ha}^{-1}\right)$ which was significantly higher in $\mathrm{C}_{1}$ but was statistically at par with $\mathrm{C}_{2}$. Available soil nitrogen in $\mathrm{C}_{3}$ and $\mathrm{C}_{2}$ was increased by 11.18 and 4.64 percent, over $\mathrm{C}_{1}$. The same trend is followed in available potassium in the soil. The maximum available soil potassium was under $\mathrm{C}_{3}$ which was increased to the tune of 24.3 per cent over $\mathrm{C}_{1}$. However, the available phosphorus was significantly higher in $C_{3}\left(20.3 \mathrm{~kg} \mathrm{ha}^{-1}\right)$ than $\mathrm{C}_{2}$ and $\mathrm{C}_{1}$, respectively. Available soil phosphorus in $\mathrm{C}_{3}$ and $\mathrm{C}_{2}$ was increased by 24.05 and 2.88 percent, respectively over $\mathrm{C}_{1}$.Among different residue management techniques, the $\mathrm{T}_{5}$ was significantly higher available soil nitrogen, phosphorus and potassium than $T_{1}, T_{2}$ and $T_{3}$ but was statistically at par with $\mathrm{T}_{4}$. In residue management techniques i.e. $\mathrm{T}_{5}$ available nitrogen in soil was increased to the tune of 17.16 percent respectively; available phosphorus in soil was increased by 41.73 percent respectively; whereas available potassium in soil was increased to a tune of 52.73 percent, respectively over $\mathrm{T}_{1}$

Table 3: Available nitrogen, phosphorus and potassium in soil $(\mathrm{kg}$ $\mathrm{ha}^{-1}$ ) as influenced by different cropping sequence and residue management techniques

\begin{tabular}{|c|c|c|c|}
\hline \multirow{2}{*}{ Treatments } & \multicolumn{3}{|c|}{ Available soil nutrients $\left(\mathrm{kg} \mathrm{ha}^{-1}\right)$} \\
\hline & $\mathbf{N}$ & $\mathbf{P}$ & $\mathbf{K}$ \\
\hline \multicolumn{4}{|c|}{ Cropping System } \\
\hline $\mathrm{C}_{1}$-Rice-wheat & 206.93 & 16.30 & 130.69 \\
\hline $\mathrm{C}_{2}$ - Rice-vegetable pea-maize & 219.53 & 16.80 & 161.09 \\
\hline $\mathrm{C}_{3}$ - Rice-yellow sarson-groundnut & 230.07 & 20.30 & 162.49 \\
\hline $\operatorname{SEm}( \pm)$ & 4.33 & 0.53 & 4.20 \\
\hline $\mathrm{CD}$ at $\overline{5 \%}$ & 17.01 & 2.10 & 16.49 \\
\hline \multicolumn{4}{|c|}{ Residue management techniques } \\
\hline $\mathrm{T}_{1}$ - Farmer's practice & 201.44 & 14.76 & 114.70 \\
\hline $\mathrm{T}_{2}-30 \%$ residue recycling & 208.00 & 16.18 & 136.44 \\
\hline $\mathrm{T}_{3}-\mathrm{T}_{2}+\mathrm{FYM}$ & 220.89 & 17.95 & 160.09 \\
\hline $\mathrm{T}_{4}-\mathrm{T}_{2}+$ biogas slurry & 227.89 & 19.22 & 170.67 \\
\hline $\mathrm{T}_{5}-\mathrm{T}_{2}+$ vermicompost & 236.00 & 20.92 & 175.18 \\
\hline $\operatorname{SEm}( \pm)$ & 3.68 & 0.94 & 2.54 \\
\hline $\mathrm{CD}$ at $5 \%$ & 10.75 & 2.75 & 7.40 \\
\hline
\end{tabular}

Crop diversification through legumes and residue management through organics showed higher available soil NPK. The probable reason might be due to higher organic matter in the soil because of residue incorporation in every season. Legumes have the ability of biological nitrogenfixation (BNF), leaf shedding, and higher root biomass, can enrich soil organic carbon (SOC), soil fertility, and redistribute of nutrients in the soil profile (Ganeshamurthy 2009; Kamanga et al. 2014) ${ }^{[9,14]}$. The poor SOC stock in soils is one of the main reasons for poor soil nutrient supply (Mandal et al. 2007) ${ }^{[18]}$ pulse crop residue with lower C:N ratio could serve as important plant nutrient source and recycling of these residues help in supplying the nutrient demand of the crop (Grant et al. 2002) ${ }^{[10]}$ and therefore residue of pulse crop increases the avialble nutrient in the soil. Including pulses in rotation may significantly effects the nutrient cycling in the soil-plant system because of its influence on soil residual fertility, and nutrient acquisition by the next crop in the rotation Vankatesh et al. (2017). Porpavai et al. (2011) ${ }^{[20]}$ at Thanjavur reported that inclusion of legume in rice-based cropping sequence contributed $0.04 \%$ increase in organic carbon. Sharma and Sharma (2003) ${ }^{[22]}$ reported that, available $\mathrm{N}$ content in soil decreased by $1.5 \mathrm{~kg}$ $\mathrm{ha}^{-1}$ after two cycles of rice-wheat cropping system but increased by $9.6,13.8$ and 14.1 and $3.5 \mathrm{~kg} \mathrm{ha}^{-1}$ after two cycles of rice-potato-mungbean, rice-wheat-mungbean, ricerapeseed-mungbean and rice-clover cropping systems, respectively.

\section{Conclusion}

Diversification of rice-wheat system as rice-yellow sarsongroundnut and rice-vegetable pea-maize and residue managements techniques where the organics are used to increase the rate of decomposition of the residue by lowering the $\mathrm{C}: \mathrm{N}$ ratio results in increased number of panicle $\mathrm{m}^{-2}$, panicle length, number of grain panicle ${ }^{-1}$, grain wt. panicle ${ }^{-1}$ results in better grain yield. Among these residue management techniques the treatment where $30 \%$ residue management through vermicompost @ $2 \mathrm{t} \mathrm{ha}^{-1}$ was applied performed best in terms of both yield and soil nutrient availabilty.

\section{References}

1. Agarwal A, Dintwa E, Joshi. Analysis of agro residue burning and present scenario in key areas of northern plains in. India International Journal of Advanced Research. 2016; 4(3):1499-1509.

2. Bejbaruah R, Sharma RC, Banik P. Split application of vermicompost to rice (Oryza sativa L.): its effect on productivity, yield components, and $\mathrm{N}$ dynamics. Org. Agr. 2013; 3:123-128.

3. Bhatt R, Kukal SS, Bausari MA, Arora S, Yadav M. Sustainability issue in rice-wheat cropping system. International Soil and Water Conservation Research. 2016; 4:64-74. 
4. Bilkis S, Islam MR, Jahiruddin M, Rahaman MM. Field performances of different organic manures on yield, yield attributes and nutrient uptake of boro rice cultivated in old Brahmaputra floodplain soils of Bangladesh. J Sylhet Agril. Univ. 2015; 2(2):195-201.

5. Chauhan BS, Mahajan G, Sardana V, Timsina J, Jat ML. Productivity and Sustainability of the Rice-Wheat Cropping System in the Indo-Gangetic Plains of the Indian subcontinent: Problems, Opportunities, and Strategies. Adv. Agron. 2012; 117:316-369.

6. Das D, Dwivedi BS, Singh VK, Datta SP, Meena MC, Chakraborty D et al. Long-term effects of fertilizers and organic sources on soil organic carbon fractions under a rice-wheat system in the Indo-Gangetic Plains of northwest India. Soil Res. 2017; 55:296-308.

7. Davari MR, Sharma SN, Mirzakhani M. Effect of cropping systems and crop residue incorporation on production and properties of soil in an organic agroecosystem. Biological Agriculture \& Horticulture. 2002; 28(3):206-222.

8. Dobermann A, Fairhurst TH. Rice: Nutrient Disorders \& Nutrient Management. Potash \& Phosphate Institute (PPI), Potash \& Phosphate Institute of Canada (PPIC) and International Rice Research Institute (IRRI), East \& South Asia Programs of PPI and PPIC, Singapore, 2000.

9. Ganeshamurthy AN. Soil changes following long-term cultivation of pulses. J Agric Sci. 2009; 147:699-706.

10. Grant CA, Peterson GA, Campbell CA. Nutrient considerations for diversified cropping systems in the northern Great Plains. Agron J. 2002; 94:186-198.

11. Hanway JJ, Heidel H. Soil analysis methods as used in Iowa state college of soil testing laboratory. Iowa Agric. 1952; 52:1-31.

12. Haque MA, Jahiruddin M, Rahman MM, Saleque MA. Usability of bioslurry to improve system productivity and economic return under potato-rice cropping system. Res. Agric. Livest. Fish. 2015; 2(1):27-33.

13. Jemai I, Ben Aissa N, Ben Guirat S, Ben-Hammouda M, Gallali T. Impact of three and seven years of no-tillage on the soil water storage, in the plant root zone, under a dry sub humid Tunisian climate. Soil Tillage Res. 2013; 126:26-33.

14. Kamanga BC, Kanyama-Phiri GY, Waddington SR, Almekinders CJ, Giller KE. The evaluation and adoption of annual legumes by smallholder maize farmers for soil fertility maintenance and food diversity in central Malawi. Food Sec. 2014; 6:45-59.

15. Keller T, Arvidsson J, Dexter A. Soil structures produced by tillage as affected by soil water content and the physical quality of soil. Soil Tillage Res. 2007; 92:45-52.

16. Ladha JK, Pathak H, Padre AT, Dawe D, Gupta RK. Productivity trends in intensive rice-wheat cropping systems in Asia. In Improving the Productivity and Sustainability of Rice-Wheat Systems: Issues and Impacts; Ladha JK, Hill J, Gupta RK, Duxbury J, Buresh RJ, Eds.; ASA Special Publication 65; ASA-CSSASSSA: Madison, WI, USA, 2003, 45-76.

17. Lungmuana, Ghosh M, Patra PK, Ghosh SK. Effect of integrating organic amendments and inorganic fertilizers on growth and yield of rice ( $c v$.IR-36) in a lateritic soil of West Bengal. Journal of Crop and Weed. 2016; 12(2):3236.

18. Mandal B, Majumder B, Bandyopadhyay PK, Hazra GC, Gangopadhyay A, Samantara RN et al. The potential of cropping systems and soil amendments for carbon sequestration in soils under long term experiments in subtropical India. Glob Chang Biol. 2007; 13:357-369.

19. Olsen SR, Cole CV, Watanable FS, Dean LA. Estimation of available phosphorus in soils by extraction with sodium bicarbonate. US. Dep. of Agric. Cric, 1954, 939.

20. Porpavai S, Devasenapathy P, Siddeswaran K, Jayaraj T. Impact of various rice based cropping systems on soil. Journal of Cereals and Oilseeds. 2011; 2(3):43-46.

21. Samra JS, Bijay-Singh JS, Kumar K. Managing crop residues in the rice-wheat system of the Indo-Gangetic plain. In Improving the Productivity and Sustainability of Rice-Wheat Systems: Issues and Impact. American Society of Agronomy, Madison, WI, USA. 2003; 65:173195.

22. Sharma SN, Sharma SH. Role of crop diversification and integrated nutrient management in resilience of soil fertility under rice-wheat cropping system. Archives of Agronomy and Soil Science. 2003; 50:345-352.

23. Srinivasan R, Alagawadi AR, Mahesh S, Meena KK, Saxena AK. Charaterization of phosphate solubilizing microorganisms from salt affected soils of India and their effect on growth of sorghum plants (sorghum bicolour (L.). Moench). Ann. Microbiol. 2012; 62:93-105.

24. Subbaiah BV, Asija GL. A rapid procedure for determination of available nitrogen in soils. Curr. Sci. 1956; 25:259-260.

25. UNEP. Fresh water under threat, south asia, vulnerability assessment of freshwater resources to environmental change. United Nations Environment Program, 2008.

26. Venkatesh MS, Hazra KK, Ghosh PK, Khuswah BL, Ganeshamurthy AN, Ali M et al. Long-term effect of crop rotation and nutrient management on soil-plant nutrient cycling and nutrient budgeting in Indo-Gangetic plains of India. Archives of Agronomy and Soil Science, 2017, 1-16.

27. Verma BC, Datta SP, Rattan RK, Singh AK. Long-Term Effect of Tillage, Water and Nutrient Management Practices on Mineral Nitrogen, Available Phosphorus and Sulphur Content under Rice-WheatCropping System. J. Indian Soc. Soil Sci. 2016; 64:71-77.

28. Yadwinder-Singh, Sindhu HS. Management of cereal crop residues for sustainable rice-wheat production system in the Indo-Gangetic plain of India. Indian National Science Academy. 2014; 80(1):95-114. 